numbers and expansions of subject fields. In recent months, for example, a librarian working with large masses of materials on the Near East or Africa has found the LC offering revisions and new numbers in quantity.

These examples are not cited to suggest that use of LC is best suited to the classified catalog, but they will, it is hoped, provide in some measure comparisons that may help in a consideration of the workability of one or the other of our major classification systems. As a practical consideration it is unlikely that any large library would be able or want to pioneer a new system for its entire collection, but it might wish to provide a complimentary medium of subject analysis for some areas, and in this case a comparison of the potentialities of LC and DC would be useful.

Finally, a word on the format and typography of this study. The cover has a simple and attractive design but the use of reproduction of typed copy with unjustified outer margins is regrettable. We are sacrificing a great deal to cost when as librarians we permit our works to be printed in an unattractive style. That it seems to be a financial necessity we may recognize, but if other readers are as annoyed as the reviewer with the bleakness of the appearance and the awkward way that every initial use of the letter I was followed by an off-line letter, it might be possible to get ALA to search for better methods of printing. In order, however, to avoid closing this review on a minor note, it seems only fair to repeat, this study has been needed, and the profession should be grateful to the Rockefeller Foundation for its interest and concern in promoting the examination and study of one medium of subject control that has been in partial eclipse for some time.-Mary Darrah Herrick, Chenery Library, Boston University.

\section{Bibliography of Slavic}

\section{Periodicals}

Bibliografija rasprava, clanaka $i$ knjizevnih radovia. I Nauka o knjizevnosti. I/1 Knjizevnost opcenito. Teorija knjizevnosti. Uporedna knjizevnost. I/2 Historija jugoslavenskih knjizevnosti. A-K-Zagreb, Yugoslav- ia: Leksikografski zavod FNRJ, 1956. xIII, 859 p.

The Yugoslav Lexicographic Institute in Zagreb has published the first volume of that series of the monumental Yugoslav Encyclopaedia which will contain the bibliography of factual, polemical, critical, and literary articles. This first volume covers the bibliography of literature and is divided into two parts: (1) literature in general, theory of literature, and comparative literature (94 pages); and (2) the history of the South Slavic literatures, A-K (pages 95-677). There is also a subject index on pages 679-806, an index of pseudonyms and initials on pages $807-831$, and an author index on pages 832859. All pages are double-columned.

The purpose of this work is to provide a retrospective bibliography of works published in the periodicals in South Slavic languages from the end of the eighteenth century up to 1945 , although the present volume ends with 1941. This was an enormous task, since the material is scattered in thousands of different periodicals published over some 150 years. Prior to publication it was necessary to classify each of the entries under an appropriate subject.

When complete, this bibliography will consist of about twenty-five volumes, of which the first fifteen will include: I-III, literature; IV-VII, Yugoslav literatures; VIII-XI, history; XII-XIII, philology and foreign literatures; XIV and XV, art and the theater. Only articles from periodicals (including scholarly and popular magazines, newspapers, annuals, almanacs, calendars, etc.) are included. Books were omitted, since another bibliography of Yugoslav books is in preparation and is scheduled for publication at an early date.

Most of the material included in this bibliography was published within the boundaries of modern Yugoslavia. However, some publications from foreign countries were also included, especially if written by Yugoslavs residing abroad or by foreigners especially interested in studies of Yugoslav history, culture or national characteristics.

Work on this bibliography was hampered by the difficulty of securing information on the date of publication of several periodicals. In the case of some periodicals it is possible 
that we may discover additional volumes at a later date. Thus, supplements to this bibliography will be inevitable. A supplement containing entries for the war years, 1941-45, will also be published.

The arrangement of entries is by broad subjects, and within each subject alphabetically by author. Each entry is numbered. On the whole it can be said that this work has been executed in conformity with sound bibliographical principles, and when complete, it will be of great value for Yugoslav scholars as well as for others who are familiar with the Serbo-Croatian language and are interesed in the literatures and cultures of the Yugoslav people.-Milimir Drazic, University of Kentucky Library.

\section{Printing and Publishing}

\section{in Alsace}

Histoire de l'imprimerie alsacienne aux XVe et XVIe siècles. Par François Ritter, Strasbourg-Paris: F.-X. Le Roux, 1955. xvi, 631p. (Publications de l'Institut des Hautes Études Alsaciennes, Vol. 14.)

It takes some daring to attempt a comprehensive study of the complex history of printing and publishing in Alsace during the fifteenth and sixteenth centuries. Problems involved touch on so many facets of cultural and social history that it becomes difficult to master the variety of topics and to evaluate the considerable literature; it is difficult also to add substantial and new information to competent studies like Charles Schmidt's Histoire littéraire de l'Alsace (1879), Karl Schorbach's Der Strassburger Frühdrucker Johann Mentelin (1932), or Paul Kristeller's Die Strassburger Buchillustration im XV. und im Anfang des XVI. Jahrhunderts (1888).

Yet the task is highly worth while. Alsace in general, and Strasbourg in particular, are key areas in the study of fifteenth and sixteenth century history. Publishing there provides dramatic illustrations for the slow disappearance of the medieval world, the growth of humanism and its new learning, the religious controversies before and during the Reformation, the interest in Germany's medi- eval vernacular literature possibly to be interpreted as the by-product of rising nationalism, the increased production of contemporary literature, including some rather bawdy writings for popular entertainment, the accomplishments of city-sponsored secular education, the development of modern science paralleled by the publication of handbooks for craftsmen, and the use of book illustrations to make the products of the press more attractive and more saleable, and also better understood.

François Ritter, well known to the historian of early printing through the compilation of the Répertoire des livres alsaciens du XVIe siècle de la Bibliothèque nationale de Strasbourg (1932-), the Catalogue des incunables alsaciens de la Bibliothèque nationale de Strasbourg (1938), and the Catalogue des incunables et des livres du XVIe siècle de la Bibliothèque municipalede Strasbourg (1948), and known to literary historians as the coauthor with Paul Heitz of the small but extremely useful Versuch einer Zusammenstellung der deutschen Volksbücher des 15. und 16. Jahrhunderts (1924) is well qualified to follow in the steps of the venerable Charles Schmidt and to write a comprehensive history of Alsatian printing and publishing.

His history of Alsatian printing is divided into two main parts. Part I covers the fifteenth century. In its first chapter the author surveys the literature on the Gutenberg question with its complicated and at times highly speculative controversies over the chronology of events preceding the publication of the 42 line Bible (including the most recent discussion over the Missale speciale). When he discusses the part which Strasbourg may have played in Gutenberg's early attempts, the author naturally shows his patriotic feelings and justifiable bias, without accepting, however, suspect evidence, like the early sixteenth century claim that the Strasbourg printer Mentelin was the real inventor of the ars nova. Chapters two to six deal with the earliest Strasbourg printers, Mentelin, Eggestein, Rusch, and others. Chapter seven, the last of Part I, is devoted to Alsatians who sought their fortunes away from home, among them Sixtus Riesinger (Naples), Michael Friburger (Paris, where he established the first press in France together with Gering and Crantz), 